\title{
ANALYSING THE DEMOGRAPHY AND MIGRATION RELATED CHALLENGES WITHIN THE INTERNAL PERIPHERY OF SOUTH- HEVES
}

\author{
Tunde BOGARDI ${ }^{\mathrm{a}}$ \\ ${ }^{a}$ Szent Istvan University, Faculty of Economic and Social Sciences, Address: 2103 Gödöllő, Páter K. \\ u.1., phone: +36-20/594-9220, e-mail: bogardi.tunde@gtk.szie.hu
}

Cite this article: Bogardi, T. (2015). Analysing the Demography and Migration Related Challenges within the Internal Periphery of South-Heves. Deturope, 7, 1: 6-20

\begin{abstract}
The purpose of my study is to perform an analysis with the application of regional statistical data, in order to understand the changes within the number of the population at South-Heves in the past period, and to the reveal its special characteristics compared to regional, national trends. The examined area is a classic internal periphery, a region "hit severely by social, economic and environmental crisis" (according to the draft proposal of Heves county's regional development concept (2014-2020)). Considering such regions, besides the examination of the intention to migrate, it is also important to see who will remain in the region. Experiences show that in case of regions with a more disadvantageous situation than average, generally classes of lower social statuses will become dominant, while as it is described by Györi-Nagy (2003), "the escape of competent classes of the population" can be observed. It results in a contra-selected local society which is unable to retain the young and ambitious.

The future of the affected regions, settlements is largely determined by the perspectives perceived by young people who live there, and who shall start their families and careers there in the near future. I have conducted an empirical research amongst high-school students living and studying at SouthHeves, focusing on issues such as whether the high-school age-group of this classic periphery is considering migration; if so, then what are the reasons, destinations, and as an important question from the aspect of the national strategy as well, how could these young people who are longing to go elsewhere manage their lives here, and how could we make them stay in their homeland (in a narrow sense). By investigating the intention to migrate, we also receive indirect answers for questions such as how could significant regional differences be reduced, and how could we close the gap in case of the most disadvantageous regions.
\end{abstract}

Keywords: migration inland and to abroad; internal periphery of South-Heves; demography and migration related challenges

\section{INTRODUCTION}

I aspire to introduce the situation of an actual region from the aspects of demography and migration in my study. In practice, I shall analyse the population retaining ability with the help of statistical data and a questionnaire survey. According to Matolcsi (1982), there are three factors that need to be present at the same time, in order for a settlement/region to retain its population: habitation, a job that ensures living costs, and a public space enabling 
the felt of "being part of a society". This concept was further developed by Csatári (1986) by describing four major aspects: the biological reproduction ability of the population, the economic sustaining ability, supplying ability, and attachment. I believe that the importance of this aspect is that instead of a situation, it describes a process, and also that his approach focuses on the relation between the individual and the society. I presumed in my analysis that the future of a region is significantly influenced by the perspectives perceived by the young people who live there, and shall start their families and careers there in the near future. In the first half of my study I provide a general outline of the situation at South-Heves through statistical data, which shall be followed by the presentation of the results of an empirical research, designed to comprehend the plans of students studying in South-Heves regarding their future education, occupation and formation of families, and also their intention to migrate inland or abroad. The high-school selected as the field of the research is the sole second-level education institution within the internal periphery of South-Heves. I attempted to understand the way this high-school age group perceives its future, whether they plan to migrate inland or to abroad, and whether they receive, and if so, what kind of advices from their environment.

\section{A CLASSIC INTERNAL PERIPHERY: SOUTH-HEVES}

Figure 1 Age pyramids - Age distribution of the population by gender

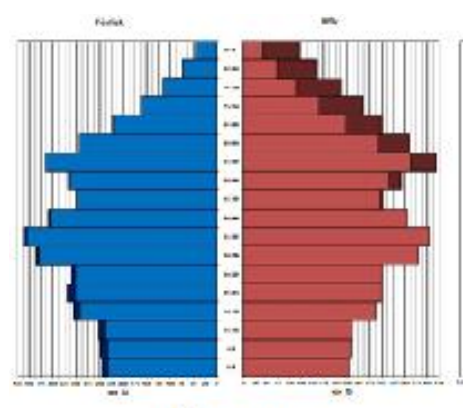

Hungary

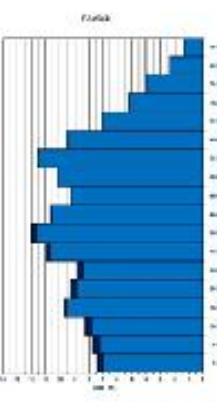

Heves County

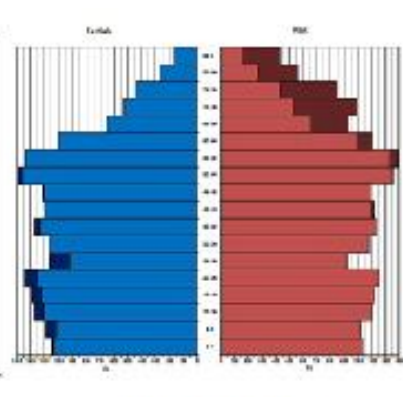

South-Heves

Though the age pyramid of Hungary and the county of Heves are not completely the same, they are both obviously urn-shaped, which indicates an ageing population with the low proportion of young people, and a higher proportion of the elderly. Both of them show a slight surplus of man within the younger age groups, while the elder groups are more and more dominated by women. South-Heves (the district of South-Heves) follows the national-county trends in several aspects (distribution of genders within the age group), 
however there is a significant difference: the larger proportion of the young age group. An age pyramid that is wide at the base suggests a young age structure, however the signs of ageing are already perceptible in spite of the higher proportion of young people, since it does not have the typical "pyramid" or "Christmas tree" shape: the increasing weight of age groups above 50 is also present.

By examining the education attainment indicators (more specifically the ratio of those older than 10 years who even have not finished the first class of primary school yet), significant regional differences are observable even within the county of Heves. The below map (see Figure 2.) demonstrates well that settlements with indicator values worse than average shape a somewhat closed block at the northern and southern, south-eastern part of the county. The high proportion of those with low educational attainment at the north is mainly explained by the also high proportion of the elderly population (typically with a low level of educational attainment) amongst many other factors. While at the southern, south-eastern part, the situation might be mostly but not exclusively linked to the higher proportion of the Roma population. According to the population census conducted in 2011., the proportion of the Roma population (Romani, Bayash) within the whole population is $3,2 \%$ on a national level, $6,3 \%$ within Heves county, and more than its double, $14,8 \%$ in South-Heves. Obviously, population census data depending on selfadmission are significantly distorted - under estimated -, the significantly higher proportion of the Roma population is still observable in South-Heves, which data in reality even exceeded $50 \%$ in case of some of the region's settlements.

Figure 2 The proportion of the population older than 10 years, who has not even completed the first class of primary school, $2011(\%)$

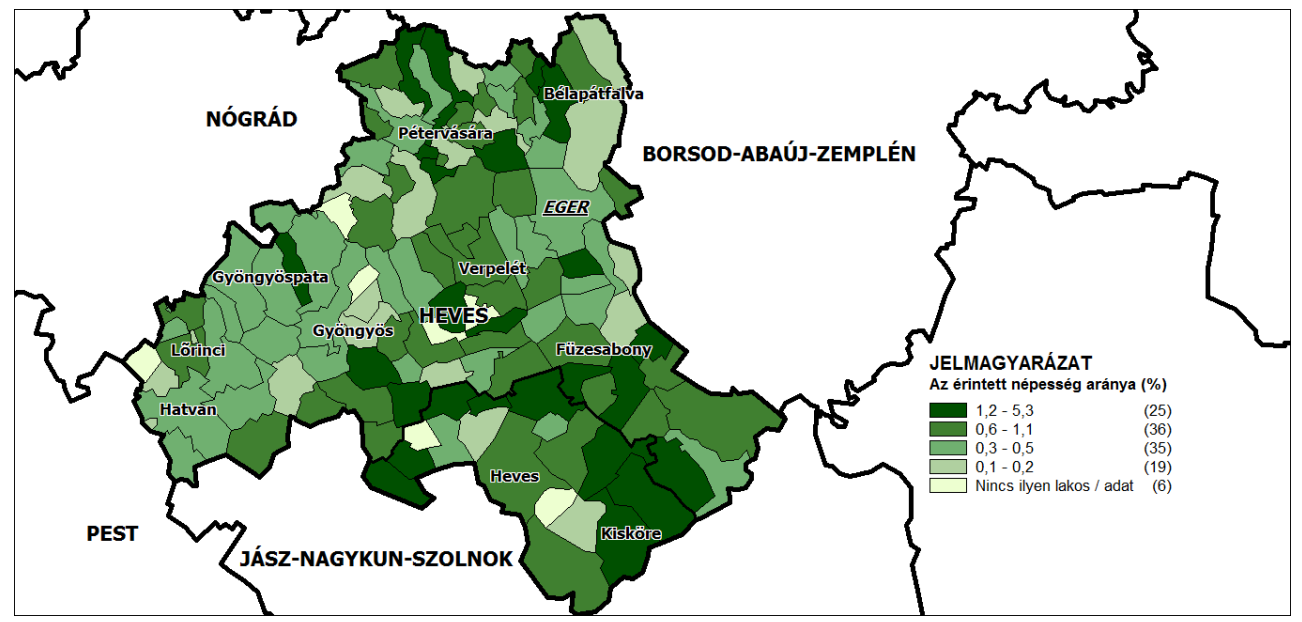


The situation is similar in case of those with a higher level of educational attainment than primary school, yet the central position of the more institutionalized settlements (Eger, Gyöngyös, Hatvan) which are able to employ people with higher qualifications is apparent (Figure 3). The figure also shows us that indicators regarding villages with a poorer supply system located in the close range of these settlements are relatively fair. The proportion of those with a university or college degree supports the central position of towns with higher education institutions (Eger and Gyöngyös) even better. The results of the analyses on educational attainment reflect well the gap existing in case of the north-western and southeastern regions, and also a sharp indicator of the existence of a social-cultural deficit.

Figure 3 The proportion of the population older than 18 years who at least graduated from high school, $2011(\%)$

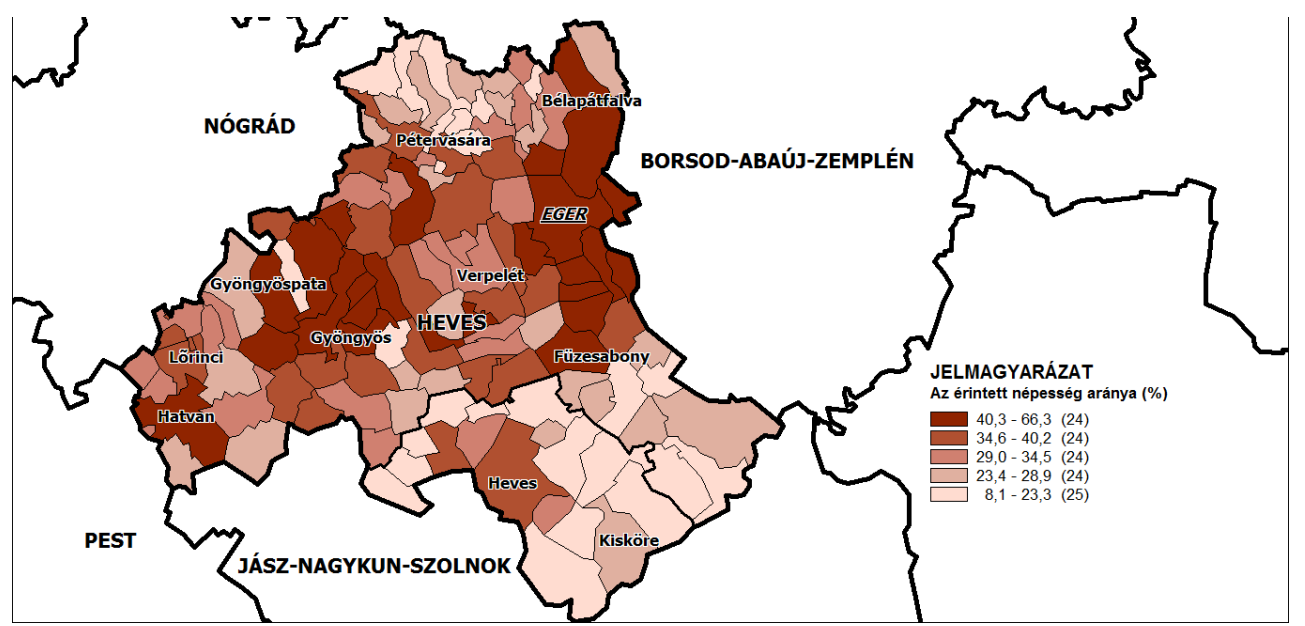

The quality of the skills of the population and indicators on employment-unemployment are linked more and more closely in today's knowledge based society. As a consequence it is not a surprise that the map demonstrating the proportion of the people employed compared to the population of active age (see Figure 4.) results in a spatial structure which is parallel to all of this. Job opportunities enabling livelihood have been concentrated to towns and larger settlements for centuries, and the human capital, the well-skilled labour force is becoming more and more appreciated amongst the factors encouraging settlement. Half of the settlements in the region of South-Heves as the subject of analysis already belong to the ones with the lowest level of employment rates within the county, and though it is not visible on the map, the situation is even worse in case of women. The lack of job opportunities in villages is the direct consequence of the winding-up of collective farms and related side-lines, since these were the largest (and in most cases the only) 
opportunities of employing the unskilled labour force. Moreover, the centre of the region was not amongst the focus points regarding industrialization, therefore long-distance commuting was the only way out for habitants of the town and its surrounding area - until they have become the victims of the economic recession that followed the regime change, when they were the first to be down-sized, since they represented a significant additional expense for employers.

Figure 4 Proportion of the employed population between the ages 15-64, 2011 (\%)

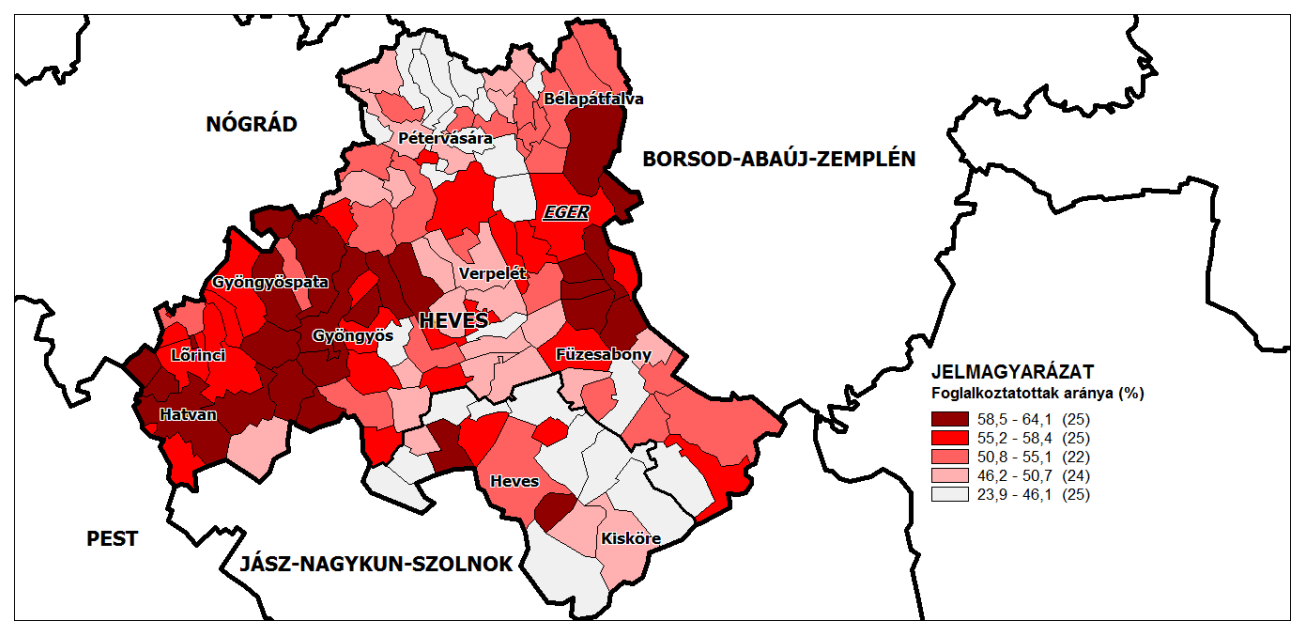

The regional structure of unemployment fails to indicate any significant shift also on a macro level in the more than two decades since the beginning of the 1990-ies, and a large part of the regions already showing the signs of employment crisis (including SouthHeves) are still not considered to be amongst the ones with an improving labour-market situation today (except for mandatory public employment, however its economy-boosting effect is largely questionable). The unemployment rate of the region therefore largely exceeds the county median level already being worse than the national average, and in certain cases it is officially close to one quarter of the population of active age (see Figure 5.) However, the actual situation is considerably worse than that. In case of most settlements, local governments are the largest employers, and a great majority of the population bases their lifestyles on social allowances, instead of wages and salaries. 


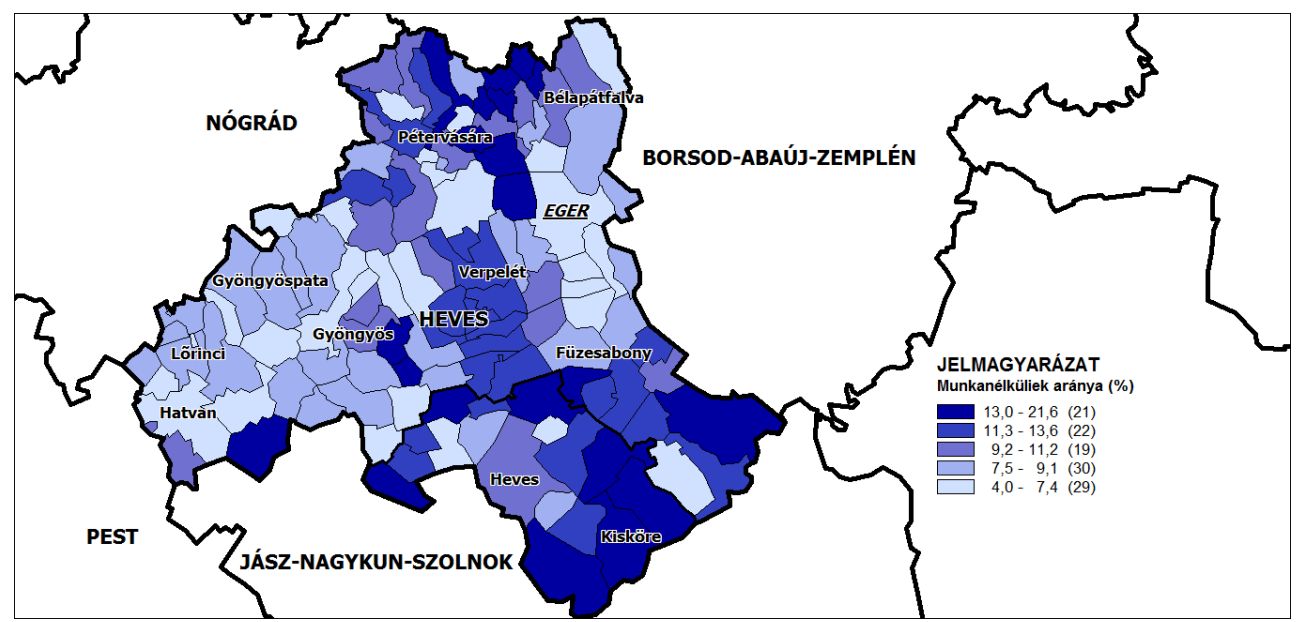

This extremely unfavourable situation of the labour force is also disappointing when considering the fact that the region belongs to one of the key recreational destinations (Tisza-tó). The actual implementation of the theoretical opportunities linked to the tourism of the Tisza-tó are hindered by several factors (a wide scale from the quality of roads to environmental disasters). Tourism has still not become the flagship sector of the region. It is apparent by observing indicators in relation to employment-unemployment and educational attainment and their causalities that the reproduction of cultural deficit and the permanent unemployment trap suggests a not too promising prospect even in the long run.

\section{MATERIAL AND METHODS}

The research was conducted in the autumn 2013 at the Eötvös József Református Education Center, which provides high-school education and vocational training. A complete enquiry has been implemented from the $9^{\text {th }}$ grade and up, in a total of 29 classes. It resulted in a number of almost 600 (596) questionnaires completed during the general class with the home teacher. Except for those who were absent due to illness or any other reason, everyone else submitted their answers. After data input I have narrowed the sample, excluding students who though study in Heves, live outside of South-Heves. I was left with 501 questionnaires, with young respondents who pursue high-school studies in South-Heves, and also live there. I shall present the results of the research in relation to them hereinafter. 


\section{Introduction of the sample}

During the evaluation of the sample consisting of 501 elements, I also aimed to perform differentiation by the form of their education and the grade of the respondent. However, I feel that the general characteristics of respondents and their families should also be considered. The examination of the gender distribution gives us 282 male and 218 female respondents, and one questionnaire with missing data. As to the family background of respondents, $35 \%$ of the mothers and $27 \%$ of the fathers have lower than completed primary education, only a little more than a half of the mothers, and $65 \%$ of the fathers completed secondary education, and $13,6 \%$ of the mothers and $8,1 \%$ of the fathers graduated from university or college. The ratios are more or less adequate to the situation described previously based on the statistical data of the region. By observing the employment activities of the parents, the level of employment is $10 \%$ higher in case of fathers/step fathers than of mothers $(63,4 \%$ of the latter and $73,8 \%$ of the former). Every fifth mother/step mother is unemployed/ jobseeker, while this ratio is $12 \%$ related to fathers. There are 28 families within the sample with both of the parents being unemployed, and 63, where one of them is. About $7 \%$ of the mothers receive child care allowances, while the proportion of pensioners is notable in case of fathers $(6,7 \%)$, which is more than double of the proportion of pensioner mothers. The number of entrepreneurs especially in case of mothers - is inconsiderable, only 12 in total. The family background of the children being analysed in the research demonstrates well the social deficit, which is also apparent in regional statistics. The only thing causing a slight contradiction was that while we are discussing an internal periphery in deprivation, yet about three quarters of students perceive the financial situation of their families to be average, $18,3 \%$ of them to be better, while $7,8 \%$ to be worse than average.

\section{RESULTS DEDUCED FROM THE ANSWERS SUBMITTED BY THE RESPONDENT STUDENTS}

In the upcoming part of my study I shall analyse the plans of respondents on forming a family, regarding their education and/or occupation, followed by their intentions on leaving the country, and South-Heves (moving to another part of the country or abroad), and I shall also examine the kind of advices respondents receive from their parents, friends and teachers regarding this latter issue. Since my analysis meets the subject of similar researches, I shall refer to these on several occasions. Such information are found within 
the results of the research conducted by Timár-Velkey (2011) regarding the Northern Great Plain, and of the Hungarian Youth 2012 research.

Considering that family planning is a key element of demographic procedures, and that being a married couple is the most ideal frame for having a child, I also enquired about whether respondents plan to live in a marriage (even in the near or far future). $57 \%$ answered with "yes for sure", about $20 \%$ said "rather yes" or was uncertain, while the proportion of those against matrimony amounted to 5\%. It is also important to note that in case of this question, no significant difference was detected either regarding the grade of the student, or the form of their education (high-school, vocational high school, vocational training).

Within the frame of the Hungarian Youth 2012 research, marriage intentions were also examined. By comparing it with the results of the research conducted in South-Heves, it is apparent, that the proportion of those who plan to enter into marriage in the future is significantly higher in South-Heves (since only 33\% answered the same question with a certain yes on a national level).

There is a considerable difference $(\mathrm{p}<0,05)$ regarding male and female respondents, when having to answer the total number of children they plan to have in the future. Surprisingly, the average of this number is 2,25 in case of boys, and 1,88 in case of girls. It must also be highlighted that both values are higher than the national average.

Educational attainment is a basic factor that influences how the local society of a region manages their lives. $65,3 \%$ of respondents said that they wish the continue their education after graduating from high-school. 34,3\% would rather start to work. This result can be better comprehended by analysing the answer of students separately, regarding the form of education. In case of high-school students, the proportion of those aspiring to continue their education was above $90 \%$, it was $61 \%$ in case of vocational high-school students, and $36,5 \%$ in case of students enrolled in vocational training. These results would show a promising shift otherwise, if migration hadn't drain qualified young people out of the region.

I presumed that it is worth further investigating the intention to migrate. The answers submitted by the respondent students are compared with the results of the Hungarian Youth 2012 research. 
Figure 6 Inclination towards studying and working abroad, within the examined age group

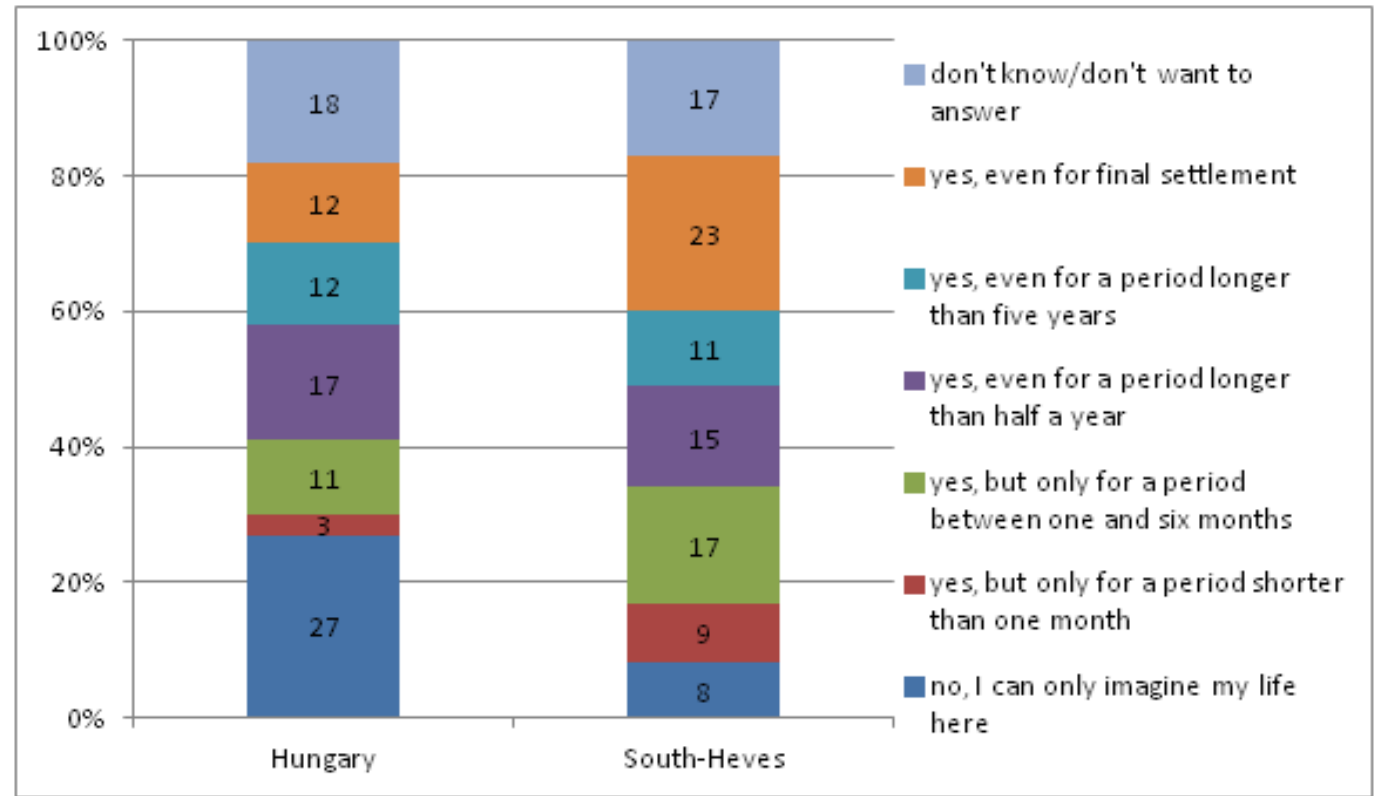

The overall results clearly show (Figure 6) that while every fourth respondent from the national representative sample said that they can only imagine their lives in Hungary, the same value is less than every tenth student in case of South-Heves. The answers also demonstrate that respondents from South-Heves would prefer a shorter-term residence abroad, and there is no significant difference in case of periods for a longer-term. It must also be noted that the number of those who would be willing to leave the country for good are the double amongst them. It projects quite serious consequences regarding the future of the demographic and intellectual renewal of the region.

I have also investigated the opinion of respondents from the South-Heves sample about studying and working in other parts of the country or abroad. 
Figure 7 Inclination towards studying and working in other parts of the country or abroad, amongst youngsters living and studying in South-Heves

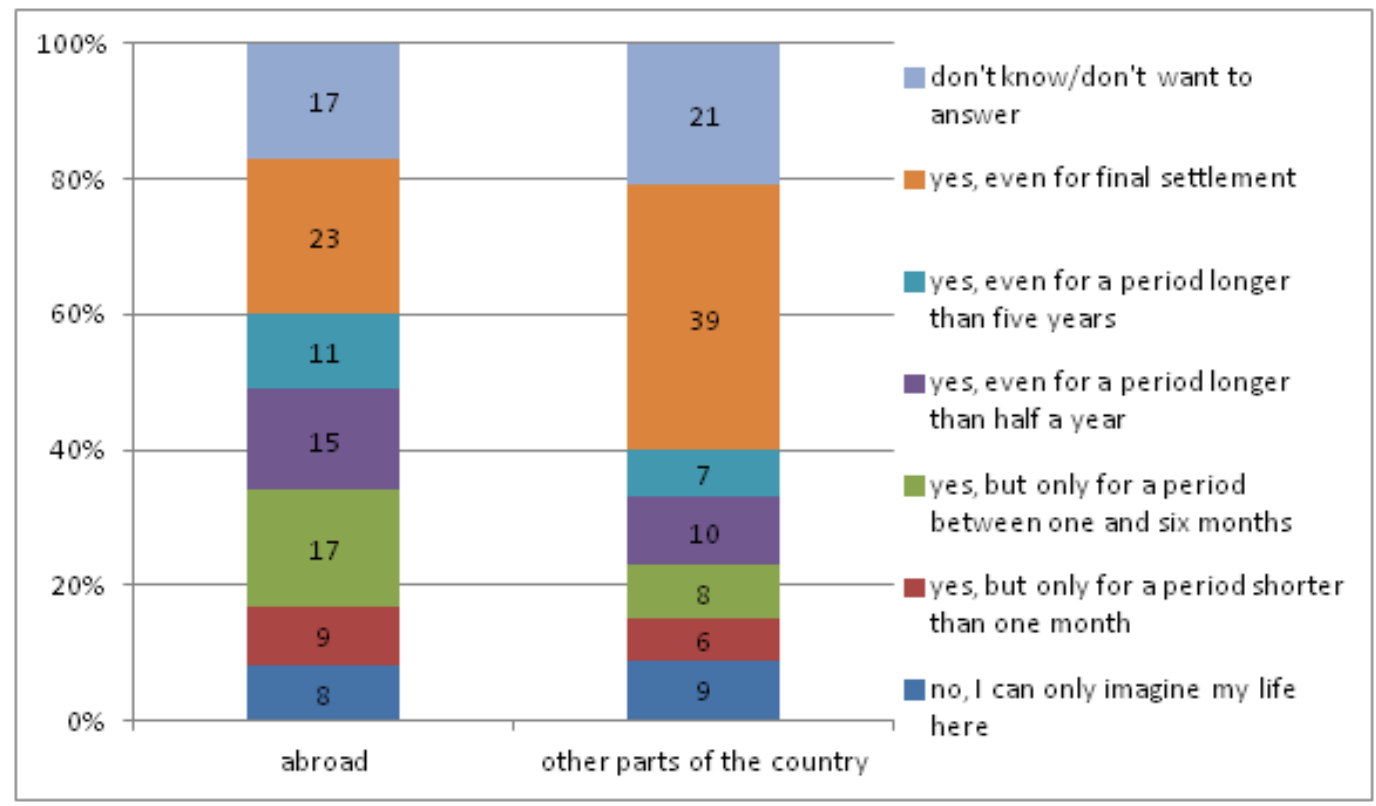

The most notable difference between the intention to migrate inland or abroad appears in case of the final destination of settlement. About $40 \%$ of the respondents would be willing to move to another part of the country for this purpose, and $23 \%$ would move even abroad. Domestic migration is more attractive for short periods, while those who prefer to move for a longer term would rather go abroad.

I examined the advices given to respondents by parents/friends/teachers about what to do after graduating from high-school, based on the research of Timár-Velkey (2011) - see Figure 7). I believe it to be an important issue to address, since the chances that an already existing intention to migrate would be actually realized are greater when supported by an external reassurance. It would not be a problem by itself, however if these individuals will not return to the region with knowledge and experience gained; the consequences of this process are extremely unfavourable for this region. 
Figure 8 Advices given by parents, friends, teachers about migration

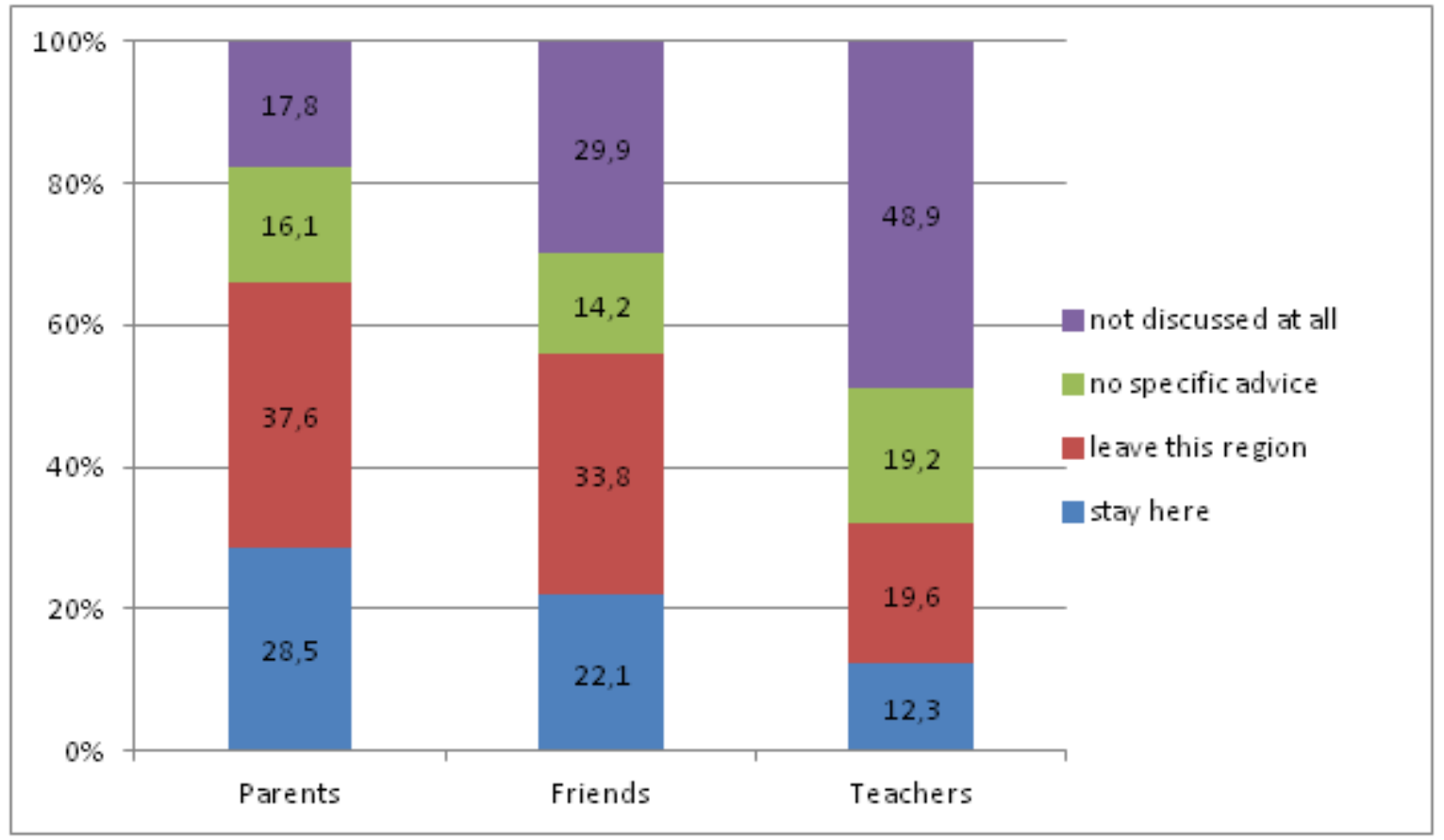

Respondent students are told by their parents to leave this region (about $40 \%$ !) as the most frequent answer. Almost every fifth of them does not talk about this issue with their parents. Those who submitted these two answers form the larger half of youngsters. They will most probably be involved in migration within a couple of years. Students receiving the advice to "stay here" amount to barely $30 \%$.

As regards friends, the proportion of those encouraging them to stay or leave (inland or abroad) is lower than in case of the advice given by parents: only a little more than every fifth was told by their friends to stay, and a third of them to leave. The answers also reveal that this topic is not necessarily discussed by youngsters with their friends. Therefore the impulse planting the idea to migrate arrives probably from other than their peers.

It was a remarkable outcome that even the school does not deal with this issue substantively. About half of the respondents claimed that the issue had not been brought up with their teachers. Then again one fifth of them said to have been encouraged by their teachers to leave South-Heves, and about $12 \%$ experienced its complete opposite.

When further examining the answers of students by the form of their education and the grade they attend, it is apparent that those who are enrolled in high-school education are told by their parents, friends and teachers to leave the region of South-Heves to a significantly larger extent. Taking this advice would lead to the further migration of those 
with a higher level of educational attainment. When comparing the advices received with the grade of the respondent, though there is a significant difference in case of parents and teachers, the tendency is still not clear. I presume that in this case, the type of the educational institution differentiates better than the grade of the respondent.

I related to the research at the Northern Great Plain by Timár-Velkey (2011) again, when I attempted to examine whether certain things are perceived to be easy or difficult for young students who live at the same place as the respondent. They had to evaluate statements on a scale from one to four, where one means very easy, four means very difficult, and in order to present a transparent chart, I have merged the categories of very easy and easy, and very difficult and difficult (Figure 9).

Figure 9 Perception of the difficulty of statements defined by Timár-Velkey in South-Heves

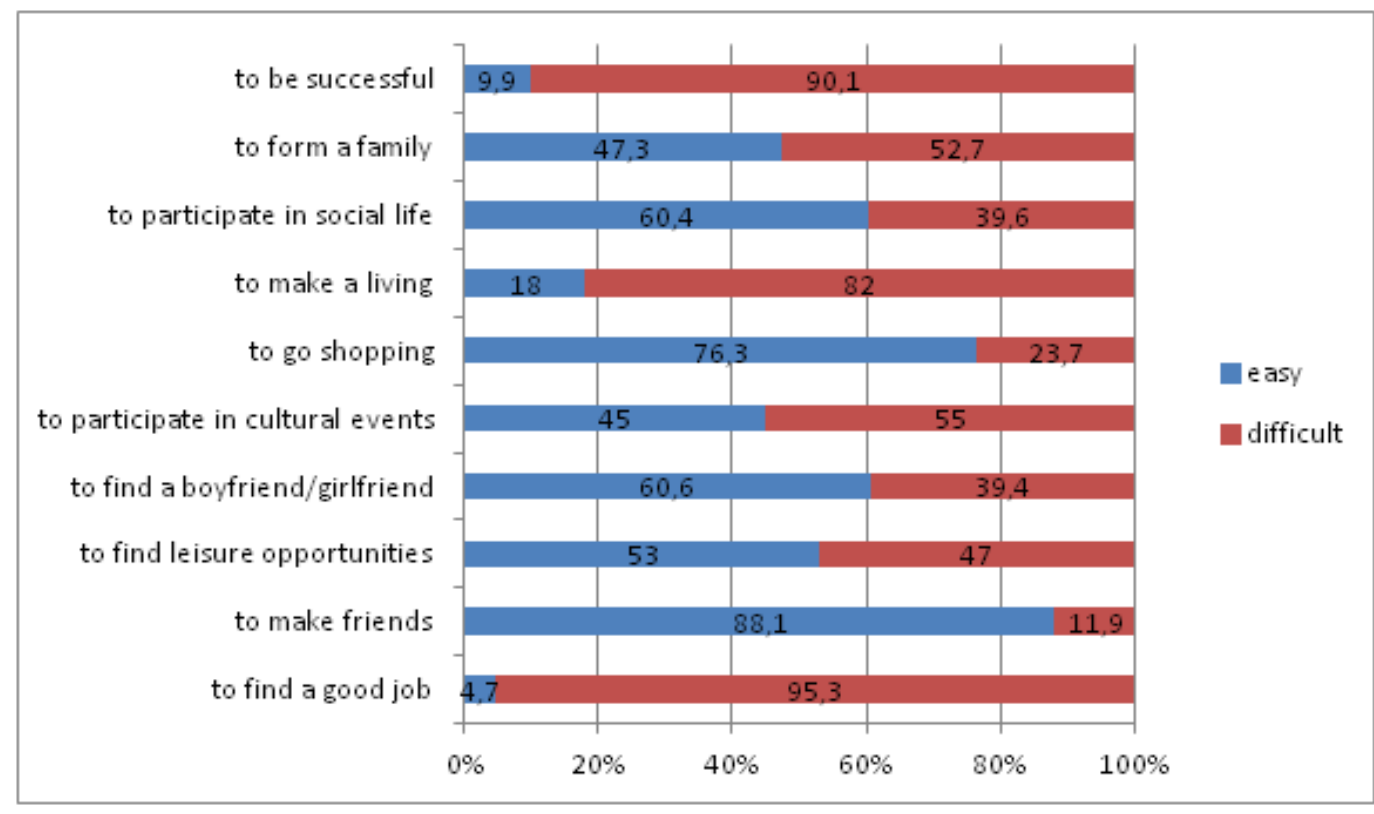

According to respondents, three things are the most difficult out of all the statements: to find a good job, to be successful and to make a living, as more than $80 \%$ found these to be difficult. However it is worth differentiating the answers demonstrated by figure 9. to a deeper extent, by the form of education and the grade of students, in order to reveal significant differences.

In relation to the perception of the difficulty of statements determined by Timár-Velkey significant differences are observable in five cases, considering the form of education. The proportion of those who believe it is difficult to find a good job and to be successful is the 
highest in case of high-school students, while making a living and forming a family is rather perceived to be difficult by those enrolled in vocational training.

By examining the grade of the respondent and the perceived difficulty of the statements determined by Timár-Velkey, three significant difficulties are revealed regarding the opinion of students of the various grades. While in case of those who have just started their studies, "only" $41 \%$ believes becoming successful to be difficult, this value becomes higher in the upper grades, exceeding $60 \%$ in some of the cases. The perception of statements referring to belonging to a society, such as "make friends" and "find leisure opportunities" is also significantly linked to the grade of the respondent. The former is rather considered to be difficult by the younger students $\left(9-10^{\text {th }}\right.$ grades). It might be explained by the fact that at that time, $9^{\text {th }}$ grade students had just been recently introduced to a society completely new to them (the questionnaires have been filled out in the beginning of November).

\section{SUMMARY}

The perishing regions in Hungary, and mostly those in a peripheral or semi-peripheral situation is not the result of the past decades. The anti-provincial politics represented by the about 40 years of socialism, collectivism and urbanisation processes caused serious damages, and the situation was further deteriorated by the disappearance of about one third of job opportunities after the regime change. As a result, unemployment which was officially non-existent to that point has been intensified to an extreme extent. Today though obviously we can not declare that decline is present everywhere, since there are prosperous provincial areas as well - the vast majority of our villages are characterized by hopelessness and the lack of a perspective. The only reason several settlements will not be depopulated or deserted in the future is because the poverty there will reproduce itself.

Migration with the purpose to work (or continue education) was on a low level in Hungary in 2007, then "as a result" of Hungary becoming part of the free movement by the Schengen agreement, and with the global crisis also beginning to approach at about the same time, it started to boost. Currently there are no accurate statistical data on the number of individuals who left the country in the past years; however, it is estimated to be around 500 thousand on a national level. A vast majority of migrants are young people, who decided to work or study in a foreign country. It must be noted that in case they fail to return within a couple of years, the extent of migration will have a number of direct and 
indirect effects (marriage, child births and tax payment will occur abroad; intergeneration relationships will deteriorate).

I revealed in my study, that the proportion of young people from the disadvantaged region of South-Heves who intend to migrate inland or abroad is significantly higher compared to national data, yet of course its actual implementation is obstructed by the lack of language knowledge and financial situation (supposedly also to a greater extent than on a national level). In order to understand, what would be necessary to make respondents stay here, or how could the already migrated be convinced or motivated to return, I have inserted questions into my questionnaire accordingly. In the first case, the priority of job creation is obvious, with two separate directions: job creation is important for those who have completed their high-school, vocational training or university studies, yet addressing the issue of employing the mass of individuals with a low level of educational attainment is also urgent - as supported by my previous (field) researches as well. Making those who have already migrated inland or abroad to return seems to be a greater challenge: respondents believe that if someone builds up an appropriate existence and forms a family abroad, it would be quite difficult to convince them to return. And even in case of returning to Hungary, they would not choose the region of South-Heves as their destination for residence, but Budapest or the western part of the country - my assumption was confirmed by the answers I have received as well.

The deteriorating social and economic indicators, and the secession of the region of South-Heves justifies the longing of young people to move elsewhere. Therefore the issue of how these young people could be convinced must be addressed. Of course it is a complex issue. It depends on the reasons of leaving, their new destinations and the quality of life they were able to achieve there, and also on the plans they have about returning. In order to understand this issue, a thorough exploration work is required for the inclusion to be planned. Then again one might ask, where and how do we want inclusion to take place? I believe that the first realistic step would be the inclusion to the level of the region (as the signs of depression shown by this region is considerable even compared to that). The national average could be the second step. The question is perfectly legitimate: will this process include the increase of the poor indicators, or the decrease of the good indicators?

From the aspect of national strategy, resolving the issue of enabling young people - the workforce and family founders of the future - to make a living here in Hungary is essential. It is also of key importance for decreasing significant regional differences, as 
Andorka (2006, 229) describes it, "complete micro-regions (...) have fallen out of the circulation of the country, sinking into a hopeless permanent poverty".

\section{REFERENCES}

Andorka, R. (2006). Bevezetés a szociológiába. Budapest: Osiris Kiadó.

Csatári, B. (1986). A községek népességmegtartó képességének fő tényezői az Alföldön. In: Novák L., Selmeczi L. (szerk.): Falvak, mezővárosok az Alföldön (pp. 779-787). Nagykőrös: Arany Múzeum.

Győri-Nagy, S. (2003). Jövőkép(esség)ek. Budapest: Kölcsey Intézet.

Matolcsi, L. (1982). Az urbanizáció hatása a közigazgatásra. Szakdolgozat. BME Mérnöktovábbképző Magyar Urbanisztikai Társaság. Budapest.

Ruff, T. (2013). Ifjúsági mobilitás: hajlandóság, lehetőségek, tervek. In: Székely L. (szerk.): Magyar Ifjúság 2012 (pp. 152-178). Tanulmánykötet.

http://kutatopont.hu/files/2013/09/Magyar_Ifjusag_2012_tanulmanykotet.pdf (2013.10.20.)

Szlávik, J. (felelős tervező) (2013). Heves megye területfejlesztési koncepciója (20142020). Javaslattevő munkaanyag.

http://www.hevesmegye.hu/files/koncepcio/javaslattetel.pdf (2013.04.30.)

Timár Judit - Velkey Gábor (2011): Kiegyensúlyozatlan nemi arányok az észak-alföldi régióban - Migrációs válaszok két Tisza-parti település fejlődési problémáira.

http://www.semigra.eu/files/web/publ/kom.pdf (2013.10.18.) 